DRUCK, Graça; FRANCO, Tânia (Org.). A perda da razão social do trabalho: terceirização e precarização. São Paulo: Boitempo, 2007, 240 pgs.

\section{Helena Hirata}

Três tipos de escritos são reunidos neste volume que resulta do paciente trabalho das pesquisadoras Graça Druck e Tânia Franco, que há mais de duas décadas se dedicam a estudar as múltiplas conexões entre saúde e trabalho, e a repercussão das políticas de flexibilização das empresas sobre a situação do emprego e a atividade dos trabalhadores. Em primeiro lugar, reflexões teóricas sobre as transformações do trabalho, sua nova "morfologia" e a "nova conformação da classe trabalhadora", segundo as expressões de Ricardo Antunes que abre o volume. Em segundo lugar, a apresentação de resultados de pesquisa de campo substantivos sobre uma região relativamente pouco estudada pelas ciências sociais do trabalho - o Nordeste - em particular a Região Metropolitana de Salvador. Os autores estudam a terceirização em empresas de ponta, com riscos industriais relevantes para a saúde e o meio ambiente. Eles apontam as principais mudanças e permanências, desde a década de 1990 aos dias atuais. Especialistas no tema, como Jacob Lima, analisam o papel atual das cooperativas no Brasil, e apontam as especificidades dessa forma de organização do trabalho na procura de objetivos similares de flexibilização produtiva. Em terceiro lugar, a consideração da dimensão subjetiva, a partir da expressão dos próprios atores sociais, principalmente dirigentes sindicais de diferentes setores, no Brasil e na França, sob a forma de depoimentos e entrevistas.

O livro reúne pesquisadores que se inscrevem no amplo debate iniciado no âmbito internacional nos anos noventa, a partir da contribuição de Robert Castel "Les métamorphoses de la question sociale”, de 1995 (trad.bras.Vozes), sobre a conjuntura mundial de precarização social e de precarização do trabalho. Se os regimes de proteção social e de direitos do trabalho variam enormemente, sobretudo entre países capitalistas avançados e os países ditos em vias de desenvolvimento, o processo de "instabilização dos trabalhadores estáveis" e a vulnerabilidade dos estatutos de emprego atinge hoje trabalhadores de ambos os tipos de países. O livro presta particular atenção à questão da erosão dos direitos dos trabalhadores neste contexto.

Pela grande riqueza de suas contribuições e pelas inúmeras pistas de pesquisa que traz, trata-se de um livro precioso que deve ser lido e divulgado.

(Recebido para publicação em maio de 2008) (Aceito em julho de 2008)

Helena Hirata. Diretora de pesquisa do Centre National de la Recherche Scientifique, França. Diretora do Laboratório Genre, Travail, Mobilités-CNRS- Université de Paris X Nanterre - Université de Paris VIII Saint-Denis. Pesquisadora visitante da Universidade de São Paulo (FAPESP) 